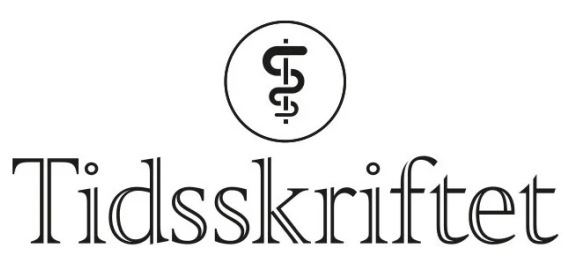

DEN NORSKE LEGEFORENING

\title{
Tall er ikke nøytral informasjon
}

\author{
MEDISIN OG TALL
}

\section{JO RØISLIEN}

jo@joroislien.no

Jo Røislien er professor i medisinsk statistikk ved Det helsevitenskapelige fakultet ved Universitetet i Stavanger, seniorforsker ved Stiftelsen Norsk Luftambulanse og profilert vitenskapsformidler. Forfatteren har fylt ut ICMJE-skjemaet og oppgir ingen interessekonflikter.

\section{Den nøytrale presentasjonen av tall og statistikk finnes ikke.}

Da jeg flyttet til London som student, fikk jeg et nytt favoritt-tall: 17. På flyet hadde jeg sittet på rad 17, og leiligheten jeg skulle bo i, lå i 17 New Road i Øst-London. Jeg så 17 overalt, og kjøpte meg et par tøfler som jeg malte tallet 17 på. Stor ble skuffelsen da jeg oppdaget at det å ha 17 som favoritt-tall var særdeles u-unikt.

\section{Tall betyr noe}




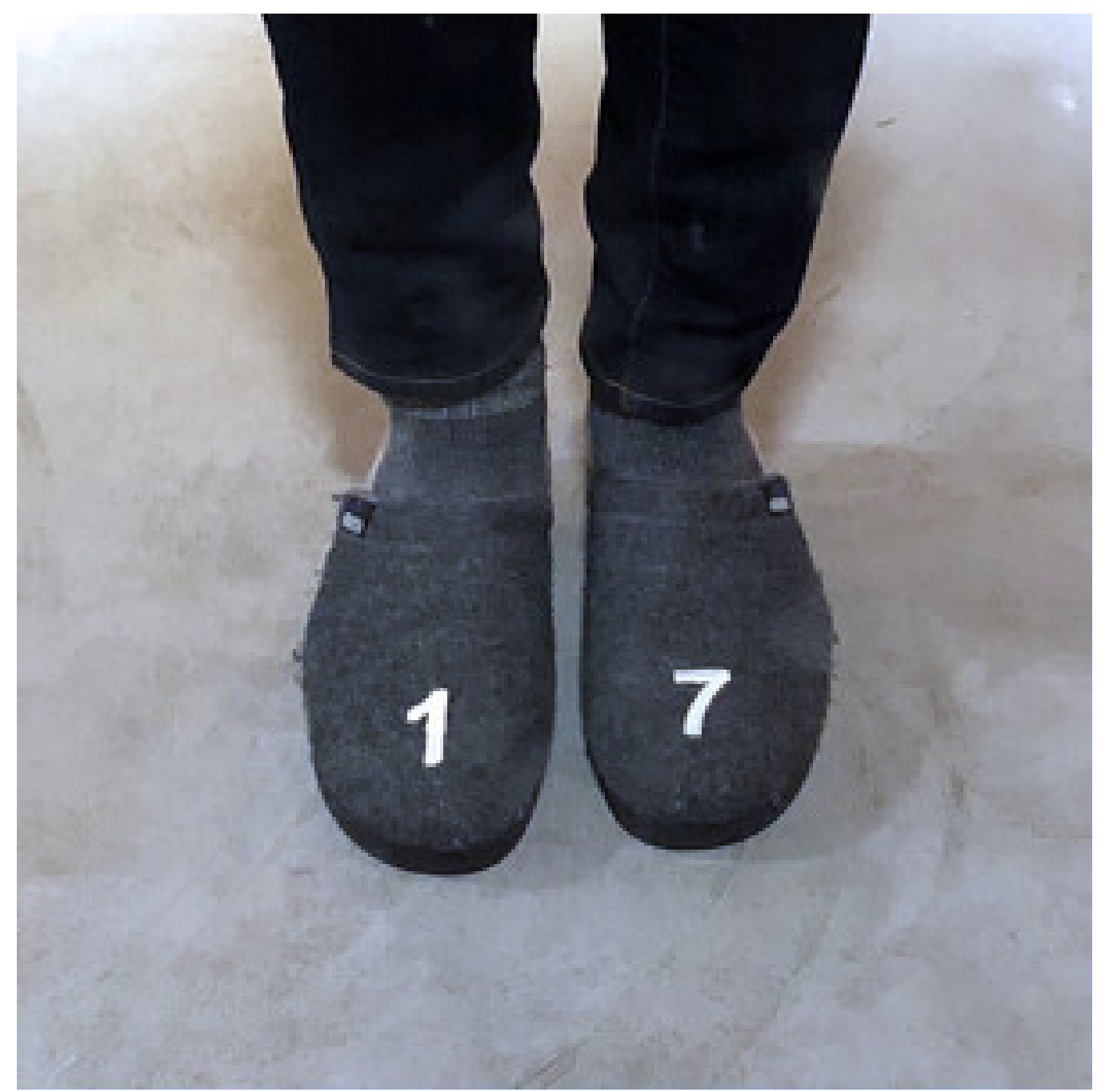

Figur 1 Tøfler med artikkelforfatterens favoritt-tall. Foto: Jo Røislien.

I uhøytidelige studier der folk skal velge et tilfeldig tall fra 1 til 20, velges tallet 17 signifikant oftest. Av tallene fra 1 til 10 er det 7 som velges oftest, og i en stor global spørreundersøkelse der folk kunne velge hvilket tall de ville, ble 7 kåret til verdens favoritt-tall (모). Alle tall fra 1 til 100 var noens favoritt-tall, mens 110 ikke ble valgt av noen. Naturlig nok. I et titallssystem oppfattes tall som går opp i 10, som ekstra systematiske - og ekstra lite unike.

At de fleste har et favoritt-tall, og at det finnes systematikk i hvilke tall vi velger oss, kan virke ubetydelig, men det forteller oss noe viktig. Det forteller at tall ikke er de nøytrale størrelsene vi gjerne liker å tenke at de er. Tall betyr noe for oss, og vi knytter ulike følelser og egenskaper til dem. Og forskningsstudier viser at hvilke tall vi presenterer, og hvordan vi presenterer dem, vil påvirke folks vurderinger og beslutninger.

\section{Risiko for å dø av covid-19}

Under covid-19-pandemien har kommunikasjon av tall og statistikk stått sentralt. Vi tenker gjerne at ved å overlevere tall og statistikk har vi overlevert nøytral informasjon, men så enkelt er det ikke.

I en studie utført av Winton Centre for Risk and Evidence Communication ved universitetet i Cambridge ble folk spurt hvor risikabel en gitt sjanse for å dø av covid-19 føltes (므). Hvis tallet ble presentert som for eksempel $5 \%$, svarte deltakerne at dette føltes som en ganske lav risiko. Men ble $5 \%$ presentert som 5 av 10o, ble dette oppfattet som en høyere risiko. Omformulert til 1 av 20 ble det oppfattet som en mye høyere risiko. Og denne 
forskjellen mellom prosent, andel av 100 og andel som 1 av noe, var gjennomgående: 1 av 5 ble oppfattet som en høyere risiko enn 20 av 10o, som igjen ble oppfattet som en høyere risiko enn $20 \%$. Tre representasjoner av det samme tallet, men det oppfattes forskjellig.

\section{Risiko for voldshandling}

Det kan være fristende å skylde på lav tallforståelse i befolkningen, men de med lang vitenskapelig utdanning gjør tilsvarende vurderinger.

I en studie ba forskere erfarne rettspsykologer og -psykiatere om å vurdere risikoen for at en psykisk syk pasient ville begå en voldshandling innen seks måneder etter utskrivning fra sykehus (3). De erfarne ekspertene ble delt i to grupper, der den ene gruppen fikk viktig bakgrunnsinformasjon presentert som prosenter, altså at det for eksempel er $20 \%$ sjanse for at en psykisk syk pasient vil begå en voldshandling etter utskrivning fra sykehus, mens den andre gruppen fikk den samme informasjonen presentert som relative frekvenser, altså at typisk 20 av 100 psykisk syke pasienter vil begå en voldshandling etter utskrivning fra sykehus.

I gruppen som hadde fått tallene presentert som en prosentvis sannsynlighet, frarådet $21 \%$ å skrive ut pasienten fra sykehus. I gruppen som hadde fått tallene presentert som relative frekvenser, var det $41 \%$ som frarådet utskrivning - nesten dobbelt så mange.

\section{Tall og beslutninger}

Vi mennesker er emosjonelle vesener, og vi skuler gjerne til følelsene våre når vi skal ta beslutninger (4). Og siden ulike tall får oss til å føle ulike ting, vil ulike presentasjoner av de samme tallene gjøre at vi tar ulike beslutninger.

Frekvenser, prosenter, desimaler, brøker. Måten vi presenterer tallene på, betyr noe, og i markedsføringssammenheng dukker dette talltipset opp på ulike blogger med ujevne mellomrom. Ønsker du å tone ned en risiko, bruker du prosenter. Ønsker du å løfte den fram i folks bevissthet, bruker du frekvenser.

Formidlingen av tallene er en viktig forlengelse av den statistiske analysen.

\section{Tøflene}

Jeg har de gamle tøflene fortsatt, med det påmalte 17-tallet fortsatt godt synlig. Men noe har forandret seg. Før representerte tøflene favoritt-tallet mitt. Nå representerer de historien om tall og følelser og om hva som skjer når objektiv informasjon skal brukes av subjektive individer. Tallet er det samme, men det betyr noe annet.

\section{REFERENCES}

1. Bellos A. 'Seven' triumphs in poll to discover world's favourite number. The Guardian 8.4.2014. https://www.theguardian.com/science/alexs-adventures-in-numberland/2014/apr/o8/seven-worldsfavourite-number-online-survey Lest 20.12.2021.

2. Freeman ALJ, Kerr J, Recchia G et al. Communicating personalized risks from COVID-19: guidelines from an empirical study. R Soc Open Sci 2021; 8: 201721. [PubMed][CrossRef]

3. Slovic P, Monahan J, MacGregor DG. Violence risk assessment and risk communication: the effects of using actual cases, providing instruction, and employing probability versus frequency formats. Law Hum Behav 2000; 24: 271-96. [PubMed][CrossRef]

4. Slovic P. The feeling of risk: new perspectives on risk perception. London: Routledge, 2010. 
Publisert: 28. februar 2022. Tidsskr Nor Legeforen. DOI:10.4045/tidsskr.21.0883

(C) Tidsskrift for Den norske legeforening 2023. Lastet ned fra tidsskriftet.no 26. april 2023. 